\title{
Evaluation of Drinking Water Storage Practices and Point Of Use (POU) Treatments for Water Purification in Rural Area around Kolhapur City, Maharashtra
}

\author{
Jadhav A. S. ${ }^{1}$, Sarkale P.S. ${ }^{2}$, Chougule S.T. ${ }^{3}$ \\ ${ }^{1,2,3}$ Department of Environmental Science, Shivaji University, Kolhapur, Maharashtra, India
}

\begin{abstract}
Safe water for drinking is one of the fundamental necessities of mankind, irrespective of his origin or socio-economic status. Waterborne diseases are one of the common causes of mortality in developing nations. The potable water status is very poor in case of rural areas, where there is an immediate requirement of sufficient and secure potable water. The purpose of the present study is to assess knowledge, attitude and practices regarding water storage and purification practices as possible determinants of diseases in the rural population around Kolhapur city. Women members which are chiefly related to household water were interviewed using questionnaires in 6 villages in Karveer district. The study showed that all households stored drinking water in containers. Though many water purifying gadgets are available in market, the rural population is deprived of these treatment options, either due to unawareness or poor economic conditions. Improper storage practices at household level can aggravate the problem of drinking water contamination. It was observed that Point of Use (PoU) Treatments for water purification can be the good solution which can solve the issue of unsafe potable water.
\end{abstract}

KEYWORDS: Drinking water storage practices, Point of Use (PoU) treatments, Rural area, Survey.

\section{INTRODUCTION}

In developing countries, Diarrhea and water-borne diseases are leading causes of mortality and morbidity (WHO/ UNICEF, 2000). Approximately $88 \%$ of diarrheal diseases are attributed to unsafe water supply, inadequate sanitation and hygiene (WHO, 2004). The proportion of population in rural areas with access to safe drinking water has a direct impact on the health of the masses. Water sources and sanitation facilities have an important influence on the health of household members, especially children (NFHS-III, 2005-06).

Diarrhea, a disease highly influenced by poor environmental conditions including water and sanitation facilities4 is one of the major killers of children in developing countries (UNICEF, 1988). Water safety in a community depends on a range of factors, from the quality of water source, storage and handling in the domestic setting. Relatively little is known about the relationship between environmental factors and child survival in many areas of developing countries. A number of studies that have been conducted in India mainly deal with demographic and socio-economic determinants of infant and child survival (Jalvaani, 2006). In order to understand the socio-cultural factors impacting on water safety, sanitation and hygiene behavior of rural community, present study was conducted to document knowledge, attitudes and practices (KAP). This information was then used to design Point of Use (PoU) Treatments which are locally relevant to improve drinking water quality at household level.

\section{MATERIAL AND METHODS}

The data was collected through a cross-sectional survey and random prospective cohort study in rural communities around six villages i.e. Ambewadi, Tamgao, Nagdevwadi Sarnobatwadi, Shiroli and Kandalgao in Karveer district.

A social survey was carried out to know the perception of people about potable water they receive in all the six selected villages. The sample size taken for analysis was 50 respondents from each village i.e. total 300 respondents from six villages. Since women are mostly related to water collection, storage and handling, the women members was focused for the survey. The interview schedule was planned to generate basic information related to household potable water quality problems, which the residents were facing, from the study villages. The data was analysed by descriptive statistics and were calculated in percentages. The first part of questionnaire was associated with preliminary information of the residents i.e. village, outline of household, age and educational 


\section{International Journal of Current Science Research and Review}

ISSN: 2581-8341

Volume 05 Issue 03 March 2022

DOI: 10.47191/ijcsrr/V5-i3-05, Impact Factor: 5.825

IJCSRR@ 2022

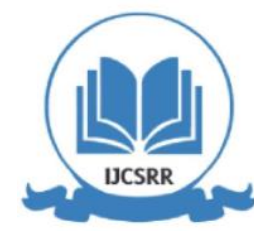

www.ijcsrr.org

status, etc. The next component was linked to sources and accessibility of potable water, storage of water, and usage of stale water, per day consumption, quality of supplied water, storage utensils and its cleanliness. Further, the attempt was done to suggest suitable water purification technique for rural community in the study area. Seven Point of Use (PoU) water treatment methods i.e. Boiling, Use of UV light for disinfection, copper vessel for storage of water, Medichlor, Solar Disinfection (SODIS), Ceramic candle filter and use of Pressure cooker. To choose suitable method among all these seven methods a scoring was given in between 1 to 3 (1 for low, 2 for fair, and 3 for good performance). For scoring seven criterions were considered like Quantity of water purified, Disinfection efficacy, (MPN \%), accessibility of purification unit and its components, simplicity of method and time required, Maintenance, Cost of treatment for per litre purified water and Personal health and safety while performing the method .

\section{RESULTS AND DISCUSSIONS}

During the interaction it was observed that each village had different major water resources for general purpose like agriculture and other activities, but drinking water sources were largely restricted to Tap water, well water and bore water. The villages like Sarnobatwadi, Shiroli and Kandalgao were supplied water only once in two or three days for a duration of 20-30 min. While Ambewadi, Tamgao and Nagdevwadi had daily water supply for 20- 30 minutes. The laboratory analysis physicochemical and bacterial analysis showed that there is major problem of bacterial contamination and increased turbidity in the study area (Jadhav A.S., 2015).

Survey results in the study area shown that most $(67 \%)$ of the respondents in all the villages complained about the poor quality drinking water supplied to them. A large number (70\%) of the residents were unhappy for the turbid appearance and colour of water. Others complained about the suspended solids in water, mostly during rainy season. Especially, the people from Sarnobatwadi and Shiroli villages were unhappy about the contamination in their drinking water. It was observed that the respondents were using a variety of combinations for of water storage in containers like stainless steel containers, ghagars (traditional water vessel), plastic ghagars, Copper 'handa' (a large container) or a ghagar or earthen vessels. (Fig. No. 1)

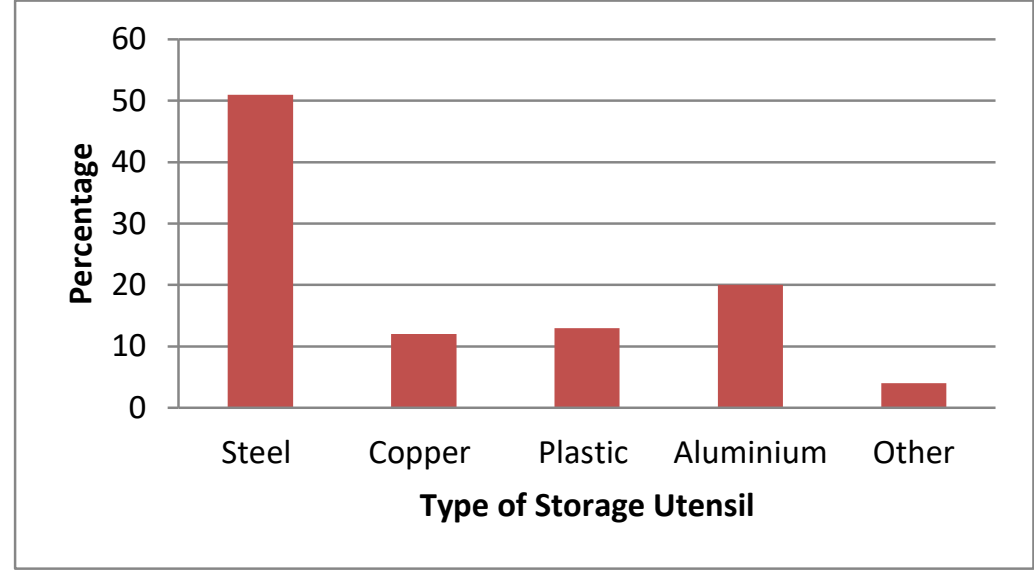

Fig.No.1 Water storage material used in study area

Very few people were using earthen vessels and that too mostly during summer season for cooling water. When enquired about health problem in the household possibly due to contaminated drinking water, many (42\%) respondents gave positive response that their family members did suffer from water borne infections. Specially, the children and old people get infected due to contaminated water during monsoon season. Further, the respondents were asked about the type of water purification methods which they follow at household level. (Fig. No. 2) 


\section{International Journal of Current Science Research and Review}

ISSN: 2581-8341

Volume 05 Issue 03 March 2022

DOI: 10.47191/ijcsrr/V5-i3-05, Impact Factor: 5.825

IJCSRR@ 2022

www.ijcsrr.org

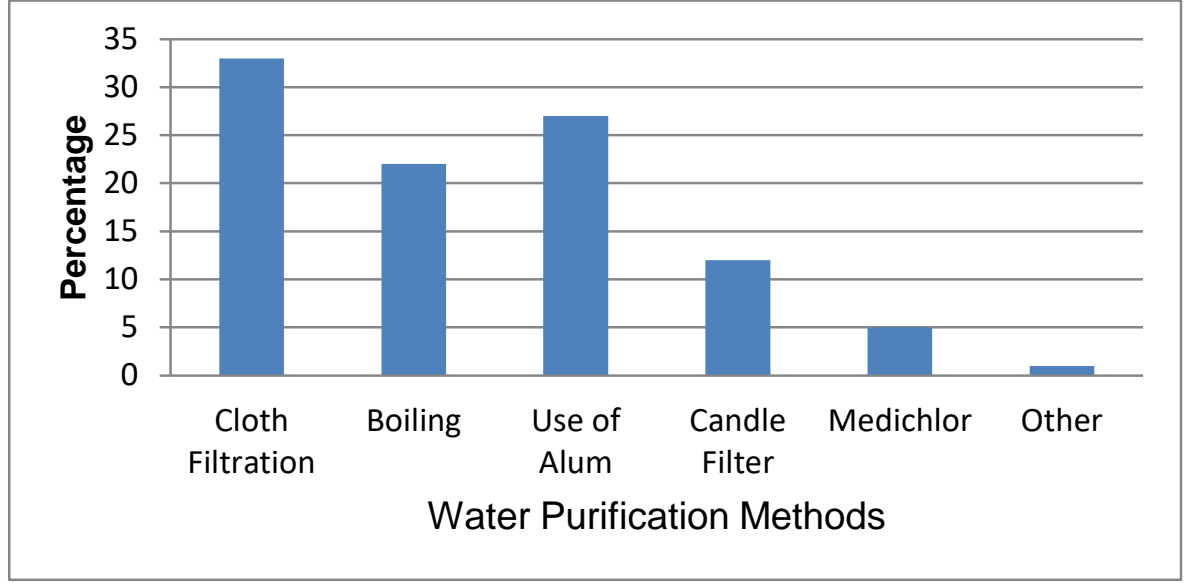

Fig. No. 2 Water purification methods followed in study area

Overall some people (38\%) having Tap water as water source, were using cloth filter (33\%) while boiling of water was practiced by $22 \%$ respondents. Use of alum for removal of suspended particles is also seems to be favorable option among rural population. The treatment was given mainly during monsoon season. Remaining $62 \%$ respondents from the study area, who used tap water, did not give any treatment to the water used for drinking purpose. When asked about the reasons for use of drinking water purification methods, if they are using, among all the respondents, 34\% people reported that the method which they are following was cost effective. While $26 \%$ respondents said that they follow the method being simple to carry out. About (23\%) of the respondents thought that the good quality of the water purifier made them to use it. While $17 \%$ said that the material required for water purification was locally easily available. The respondents were also asked about use of water purifier for drinking water purification. Only some (30\%) respondents treated drinking water through standard steel ceramic candle filter while merely 5\% used the branded table top water purifier. However, the remaining majority (65\%) did not have any access to any household level water purification method, this was attributed to several reasons.

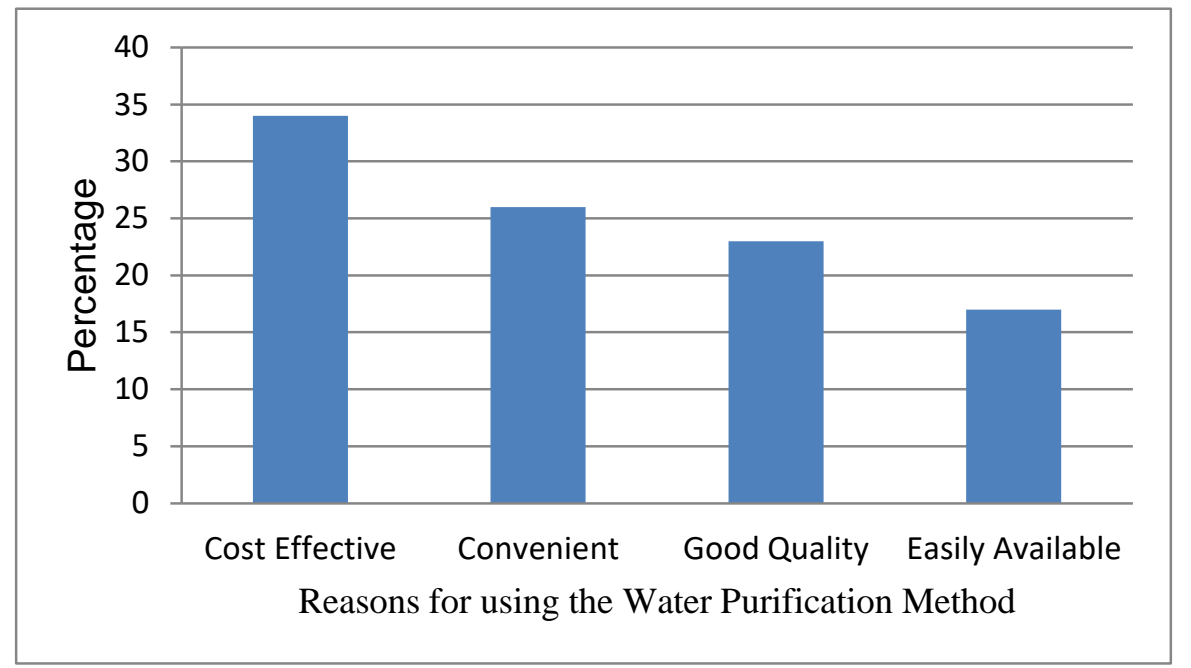

Fig. No.3. Reasons for using the drinking water purification method in the study area.

Many governmental missions related to clean drinking water are promoting the Point of Use (PoU) water treatments as the solution to the problem of poor quality drinking water in poor communities in the developing countries (Sobsey et. al., 2008). These methods or devices work to improve the non potable water into fit to drink water. People should be sufficiently motivated and committed to integrate PoU's in their daily lives by providing them with accessible and appropriate user-friendly methods of water purification. 


\section{International Journal of Current Science Research and Review}

ISSN: 2581-8341

Volume 05 Issue 03 March 2022

DOI: 10.47191/ijcsrr/V5-i3-05, Impact Factor: 5.825

IJCSRR@ 2022

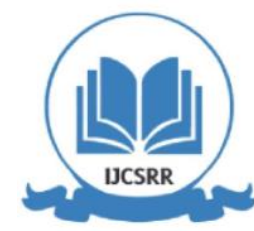

www.ijcsrr.org

During the study Seven Point of Use (PoU) water treatment methods i.e. boiling, UV disinfection, copper vessel, Medichlor, SODIS, Ceramic candle filter and Pressure cooker were applied for drinking water purification. To choose suitable method among all these seven methods a scoring was given in between 1 to 3 (1 for low, 2 for fair, and 3 for good performance). For scoring, seven criterions were considered and suitable PoU method was isolated which would be useful for rural population (Table No. 1).

Table No.1. Comparison of the Score of seven criteria assigned to the drinking water purification methods studied

\begin{tabular}{|c|c|c|c|c|c|c|c|c|c|c|}
\hline $\begin{array}{l}\text { Sr. } \\
\text { No. }\end{array}$ & $\begin{array}{l}\text { Method of } \\
\text { water } \\
\text { purification }\end{array}$ & $\begin{array}{l}\text { Water } \\
\text { quantity } \\
\text { produced }\end{array}$ & $\begin{array}{l}\text { Availability } \\
\text { and supply } \\
\text { chain } \\
\text { requirements }\end{array}$ & $\begin{array}{l}\text { Simplicity } \\
\text { and Time } \\
\text { for } \\
\text { treating } \\
\text { water }\end{array}$ & $\begin{array}{l}\text { Mainte- } \\
\text { nance } \\
\text { of the } \\
\text { method }\end{array}$ & $\begin{array}{l}\text { Cost } \\
\text { to } \\
\text { treat }\end{array}$ & $\begin{array}{l}\text { Disinfection } \\
\text { efficacy }\end{array}$ & $\begin{array}{l}\text { Health } \\
\text { and } \\
\text { Safety }\end{array}$ & $\begin{array}{l}\text { Total } \\
\text { Score }\end{array}$ & Rank \\
\hline 1. & Boiling & 2 & 2 & 3 & 3 & 1 & 3 & 1 & 15 & 3 \\
\hline 2. & $\begin{array}{l}\text { Solar } \\
\text { Disinfection } \\
\text { (SODIS) }\end{array}$ & 1 & 2 & 1 & 3 & 2 & 1 & 2 & 12 & 5 \\
\hline 3. & $\begin{array}{l}\text { Ceramic } \\
\text { candle } \\
\text { filtration }\end{array}$ & 2 & 2 & 2 & 2 & 1 & 2 & 3 & 14 & 4 \\
\hline 4. & $\begin{array}{ll}\text { Use } & \text { of } \\
\text { Copper } & \\
\text { Vessel } & \end{array}$ & 2 & 2 & 1 & 2 & 1 & 1 & 3 & 12 & 5 \\
\hline 5. & $\begin{array}{l}\text { Use of } \\
\text { Medichlor }\end{array}$ & 3 & 1 & 3 & 3 & 3 & 2 & 2 & 17 & 2 \\
\hline 6. & $\begin{array}{l}\text { UV } \\
\text { disinfection }\end{array}$ & 1 & 1 & 1 & 1 & 1 & 2 & 1 & 8 & 6 \\
\hline 7. & $\begin{array}{ll}\text { Use of } \\
\text { Pressure } \\
\text { Cooker }\end{array}$ & 3 & 3 & 3 & 3 & 1 & 3 & 3 & 19 & 1 \\
\hline
\end{tabular}

\section{CONCLUSION}

The social survey based on water quality assessment showed that there is major problem of water quality in the study area. The seven methods selected for drinking water purification are relatively common simple, cost effective and can be used in rural households. It is observed that pressure cooker method achieved highest score of 3., due to its higher coli form disinfection efficiency, availability, simplicity and water quantity produced. Pressure Cooker works on the principle of autoclave used in microbial laboratory where most of the microorganisms are destroyed. Pressure cooker is available in many rural households and therefore it can play a great role in providing safe drinking water to rural masses. Those poor who do not have access to pressure cooker yet, government should take initiative to provide rural poor communities with free pressure cooker in each household. This besides providing PoU clean drinking water would be cost effective solution on a large scale. This initiative will not only take care of disinfection of potable water, but as bonus will save large amount of cooking firewood energy

\section{REFERENCES}

1. WHO/UNICEF Joint Monitoring Program me for Water Supply and Sanitation, Global water supply and sanitation assessment, report, 2000, WHO, Geneva. http://www.who.int/water sanitation health/monitoring/jmp2000.pdf [accessed 30 October 2006]

2. World Health Organization. Water Sanitation and Hygiene, Facts and Figures, March 2004. WHO, Geneva. http://www.who.int/ water sanitation health/publications /factsfigures04/en/ [accessed 30 October 2006]. 


\section{International Journal of Current Science Research and Review}

ISSN: 2581-8341

Volume 05 Issue 03 March 2022

DOI: 10.47191/ijesrr/V5-i3-05, Impact Factor: 5.825

IJCSRR@ 2022

3. Jalvaani (Newsletter on Rural Water and Sanitation in India), July to October, 2001, 4(2).

4. National Family Health Survey (NFHS-3), India, 2005-06: IIPS, Mumbai, India.

5. UNICEF, The state of World's children, UN, New York, 1988.

6. Jadhav A. S. and J. S. Samant, (2015), Evaluation of Point-of-Use (PoU) Drinking Water Treatment Methods for Removal of Coliforms in rural households, Indian Streams Research Journal Vol.- 5 , Issue - 7 ,p.p.1-8.

7. Sobsey M. D., C. E. Stauber, L. M. Casanova, J. M. Brown and M. A. Elliott, (2008), Point of Use Household Drinking Water Filtration: A Practical, Effective Solution for Providing Sustained Access to Safe Drinking Water in the Developing World, Environ. Sci.Technol., Vol. 42, pp 4261-4267.

Cite this Article: Jadhav A. S., Sarkale P.S., Chougule S.T. (2022). Evaluation of Drinking Water Storage Practices and Point Of Use (POU) Treatments for Water Purification in Rural Area around Kolhapur City, Maharashtra. International Journal of Current Science Research and Review, 5(3), 635-639 